\title{
Sjögren's syndrome: clinical dentistry case management sjögren's syndrome: case report
}

\author{
Élcio Magdalena Giovani ${ }^{1 *}$, Kelly Cristine Tarquinio Marinho ${ }^{2}$, Ruth Andia-Merlin ${ }^{3}$, Bruno Vieira Caputo ${ }^{4}$, Gilberto Araujo Noro-Filho ${ }^{4}$, \\ Camila Correia dos Santos ${ }^{5}$, Alfredo Mikail Melo Mesquita ${ }^{6}$ and Adriana Castilho $^{7}$ \\ ${ }^{1}$ Chairman, PhD, Professor, Integrated Clinic Discipline. Coordinator of Center for Studies and Special Service for Patients. Professor, Postgraduate Dentistry \\ Courses, UNIP, São Paulo, SP, Brazil \\ ${ }^{2}$ Associate Professor, MD in stomatology, UNIP, São Paulo, SP, Brazil \\ ${ }^{3}$ Associate Professor, Integrated Clinic and Center for Studies and Special Service for Patients, UNIP. São Paulo, SP, Brazil \\ ${ }^{4}$ Associate Professor, PhD, UNIP, São Paulo, SP, Brazil \\ ${ }^{5}$ Associate Professor, PhD student, UNIP, São Paulo, SP, Brazil \\ ${ }^{6} \mathrm{MD}$, PhD- Prosthodontics, Head professor of Prosthodontics- Paulista University- São Paulo \\ ${ }^{7} \mathrm{MD}$ in stomatology, UNIP, São Paulo, SP, Brazil
}

\begin{abstract}
The Syndrome of Sjögren (SSj) is a chronic systemic illness of auto-immune etiology that affects mainly the exocrine glands, especially salivary and lacrimal. The objective of this case report was to present the importance of the diagnosis of the illness, as well as the recognition and accompaniment of the clinical case relating the systemic alterations to the buccal ones. The clinical condition of the illness and its implications had remained for long periods characterized for phases of increase and remission until the definitive diagnosis of non-Hodgkin's lymphoma resulting in generalized prostration, and death. The multiprofessional relation is important front to the case, which had to the appearance of diverse general and buccal alterations. The options of dental treatment as the lasertherapy, oral health guidelines and control of the signals and symptoms decurrent of the illness become the intervention of the excellent.
\end{abstract}

\section{Introduction}

The Syndrome of Sjögren (SSj) is a chronic systemic illness of autoimmune etiology that acomete mainly the exocrine glands, especially salivares and lacrimais $[1,2]$.

Dry mouth/ hyposalivation and xerophthalmia are explained by tissue inflammation that generates replacement of the acini and ducts of the salivary and ocular glands by fibrous tissue $[3,4]$.

There are theories that relate genetic, environmental, immunological and viral factors to determine the etiology of this syndrome [5-7].

According to the criteria of the European Community classification of 2002 [8], the SSj can be divided into two stages: the primary form is characterized by signs and symptoms of dry mouth/ hyposalivation and xerophthalmia and the secondary form by rheumatoid arthritis, systemic lupus erythematosus, systemic sclerosis, cirrhosis primary biliary and non-Hodgkin's lymphoma [9].

Nowadays, the cure for SSj is unknown, however it is known that there is a predilection for the feminine gender in the fourth and fifth decades of life and rare in children, although there are clinical studies that related this situations [10].

The diagnosis of the syndrome is based on anamnesis, clinical signs and laboratory tests [7]. The differential diagnosis should be based on the set of signs and symptoms, as well as the clinical identification allied to the complementary exams. The dentistry plays an important role in the early diagnosis of the disease, since there are characteristic oral manifestations, such as dry mouth followed by hyposalivation, burning of the jugal and lingual mucosa, taste alterations, fissured and despapilated tongue, erythematous and atrophic mucosa and predisposition to fungal infections mainly oral erythematous candidiasis [10-17].

Dry mouth was related or not to the decrease of the salivary flow, resulting from the hypofunction of the major and minor salivary glands. Flow and salivary composition vary according to stress, age, diet and systemic diseases [17-21].

The oral microbiota associated with systemic alterations, drug use, salivary flow, buffer capacity and $\mathrm{pH}$ (intermediates and lows) can determine the risk of caries, periodontal disease and fungal infections [22-25].

The objective of this study was to present the importance of the diagnosis of the disease, as well as the recognition and follow-up of the clinical case, relating the systemic changes to the buccal ones.

Correspondence to: Elcio Magdalena Giovani, Paulista University -Indianópolis Campus - São Paulo, SP, R. Dr. Bacelar, 1212, São Paulo - SP (04026-002), Brazil, Tel: (55+11) 5586-4066. E-mail: elciomg@unip.br

Key words: general and oral alterations, lymphoma, rheumatoid arthritis, sjögren's syndrome

Received: January 03, 2017; Accepted: January 29, 2017; Published: January 31, 2017 


\section{Case report}

A 64-year-old female patient, leukoderma caucasian born in São Paulo- Brazil residing in Brazil, the United States, France and Switzerland, at the upper school level, attended at Center of Study of Special Patient (CEAPE) at Paulista University - São Paulo, with diagnosis of several pathologies, confirmed through medical examinations and laboratories. Initially we performed a clinical examination consisting of anamnesis and extra physical examination (Figure 1) and intra-buccal examination. The patient reported the history of the diseases that she suffered from the beginning to the present day, when she was 35 years old, she presented the first rheumatic crisis, evolving in rheumatoid arthritis in the period of one year and a half, resulting in deformities in the hands and feet and the compromise of locomotion, followed by pain and great suffering. Due to the aesthetic impairment, she performed surgery in Switzerland on implantation of silicone prostheses in the backs of the hands and feet bilaterally (Figure 2A and B), however, they were rejected twice. For many years, she had used systemic corticosteroids in phases of remission and exacerbation of rheumatoid arthritis, after 13 years of treatment there was a slight improvement in pain with arthritis, however deformities were present. During the period of remission of the clinical condition of arthritis occurred other manifestations such as reduction of salivary, ocular and genital fluids, characterizing dry keratoconjunctivitis. Also presented brittle hair, dry skin, and opportunistically fungal infections (Candidiasis) on the buccal and genital site repeatedly. At this stage, the patient reported dry mouth and difficulty in swallowing food, altered taste and mouthfeel sensation. The tongue was stripped tongue, favoring the proliferation of fungi and bacteria. Xerophthalmia was diagnosed by the ophthalmologist through the Schimer I and II and Break Up Time (BUT) tests. The diagnosis of Sjogren's Syndrome was confirmed and the disease progressed rapidly. After a few years, generalized lymphadenopathies occurred and consequently the need for surgical removal of 16 cervical lymph nodes, further compromising the aesthetics and self-esteem of the patient (Figure 3). In another moment the surgical removal of another 9 nodules was performed again. We observed a volumetric increase (parturition) of the parotid glands (Figure 4) and physical examination in the mouth, presence of all teeth in the arches, dry mucosa, shiny in all its extension, reddish coloration, cleft tongue, fissured and presence of long-lasting (22 days) 2 ulcerated lesions, extremely painful, with fibrinolytic and halo

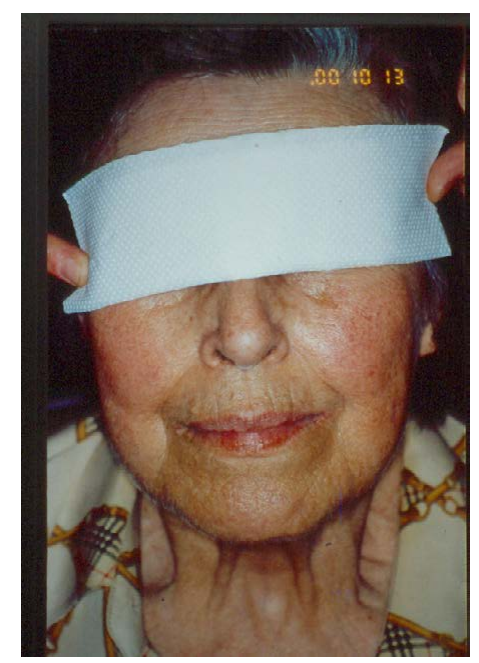

Figure 1. A 64-year-old female leukoderma patient, diagnosed with secondary Sjögren's Syndrome.
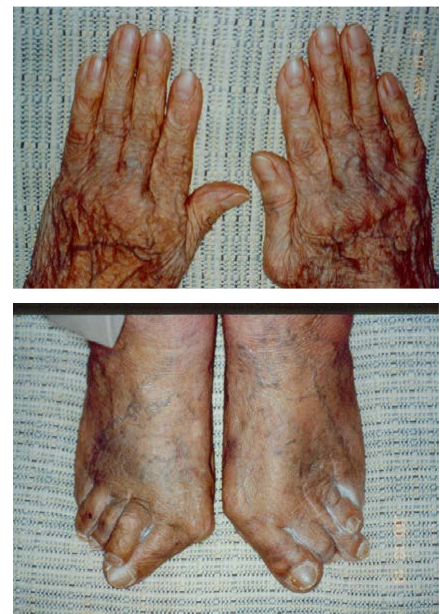

Figure 2 (A \& B): Image of the silicone prostheses in the backs of the hands and feet bilaterally performed in Switzerland, however they were rejected twice.

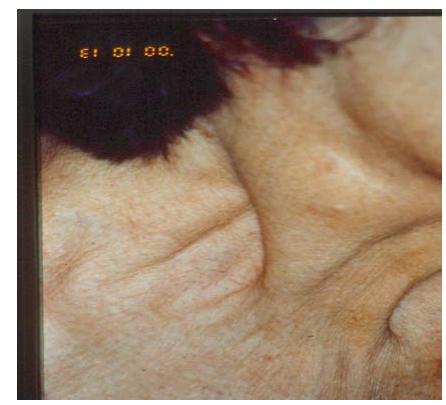

Figure 3. Image of cervical emptying performed in the lymphatic chain bilaterally.

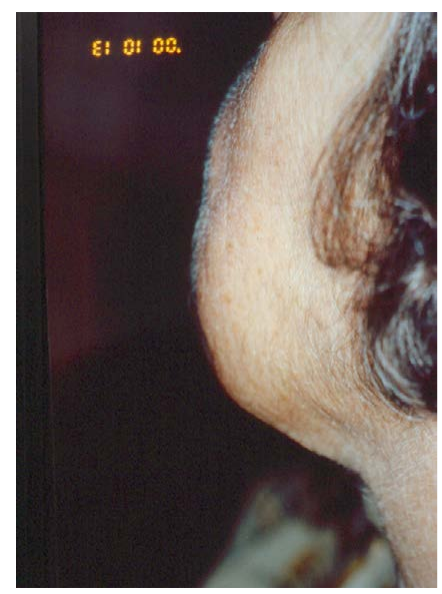

Figure 4. Image of swelling of the right parotid gland.

erythematous, measuring approximately 0.5 to $1.2 \mathrm{~cm}$ in diameter in the belly and the posterior portion of the tongue. An incisional biopsy was performed, whose histopathological anatomical result was of non-specific chronic inflammatory process, in both cases. After the result, a laser therapy with low power intensity (Gallium Arsenide and Aluminum - GaAlAs) at $790 \mathrm{~nm}$ and $30 \mathrm{~mW}$ was scheduled for 2 minutes in a punctual manner on each lesion at an energy density of $4 \mathrm{~J} / \mathrm{Cm}^{2}$, repeating the application after 24 hours and not having undergone a clinical examination of the lesions (Figure 5). Severe hyposalivation made it impossible to measure salivary flow, buffer 


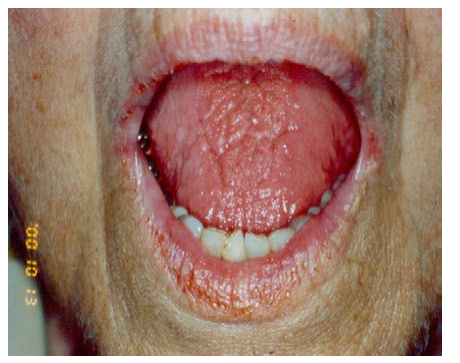

Figure 5. Anterior view presenting angular cheilitis, dry and cracked lips and fissured and despapilated tongue. Photo after removal and treatment of lesions with laser therapy.

capacity and $\mathrm{pH}$, using the DentoBuff kit; however, for artificial xerostomic control, artificial saliva, ginger crystals and brave lemon tablets, Biotene ${ }^{\circledast}$ tooth dentifrices and Jonhson \& Jonhson's KY ${ }^{\circledast}$ gel for genital and oral lubrication were recommended. Two polypropylene trays were made for daily use with acidulated fluorine gel, maintaining control of caries. The patient was also undergoing gynecological treatment due to ulcerous manifestations similar to those presented in the oral cavity, and her gynecologist reported on multiple lesions in the posterior vaginal wall, 1.5 to $2 \mathrm{~cm}$ in diameter, with a hyperemic halo and palpation pain. At the moment, oncological cytology of the posterior vaginal dome, colposcopy and histopathological anatomy of the lesion were performed, as well as hematological exams, resulting in non-specific chronic colpitis in an acute outbreak of fibrinoleukocytic crust, outbreaks of erosion, exocytosis and spongiosis: culture of the vagina and urethra positive for Enterococus SP. The recommended medical treatment was Decadron ${ }^{\oplus} 60 \mathrm{mg}$ orally, once a day, reducing the dose gradually and being maintained for 3 months, because when the corticoid was suspended, the ulcers recurred. Concomitant to the installed complications, it presented pulmonary complications that justified the pneumologist's follow-up. All clinical condition revealed so far, remained for long periods characterized by phases of exacerbation resulting in generalized prostacy when it is diagnosed Non-Hodgkin's lymphoma. The spleen and liver were compromised, including liver biopsy and metastases were confirmed by CT scans, magnetic resonance imaging and laboratory tests, indicating the presence of neoplastic cell markers. From the diagnosis of Sjögren's Syndrome the patient was constantly accompanied by multiprofessional team and complementary examinations were performed routinely, however, she died 2 months after the confirmed diagnosis of lymphoma.

\section{Discussion and conclusion}

The diagnosis of secondary Sjögren's Syndrome accompanied by rheumatoid arthritis and non-Hodgkin's lymphoma was performed by the patient's physician and followed the criteria of the European Community Classification of 2002 (Vitali et al., 2002) [8] using clinical examination and follow-up examinations. The secondary form of SSj is verified in $8 \%$ of the diagnoses of the disease, which makes this significant clinical report [26].

The multiprofessional team were crucial in the diagnosis, treatment and prognosis, resulting in improvements in the clinical condition of the disease. The dental treatment plan should be based on oral hygiene guidelines, control of signs and symptoms arising from the disease and complementary therapies such as lasertherapy promote quality of life to the patient.

\section{Competing interests}

The authors have declared that they have no conflicts of interests.

\section{Funding}

None

\section{Patient consent}

The case report was approved by the Ethics Committee of Paulista University (643/09), and the patient signed the consent form.

\section{References}

1. al-Hashimi I (2001) The management of Sjögren's syndrome in dental practice. $J \mathrm{Am}$ Dent Assoc 132: 1409-1417. [Crossref]

2. Bowman SJ, Pillemer S, Jonsson R, Asmussen K, Vitali C, et al. (2001) Contributors to and participants at the workshop revisiting Sjogren's Syndrome in the new millennium: perspectives on assessment and outcome measures. Report of a workshop help on 23 march 2000 at Oxford, UK. Rheumatology (Oxford) 40: 1180-1188. [Crossref]

3. Delaleu N, Jonsson R, Koller MM (2005) Sjögren's syndrome. Eur J Oral Sci 113 101-113. [Crossref]

4. Felberg S, Cordeiro H, Sato EH, Martini Filho D, Nishiwaki-Dantas MC, et al. (2008) [Reproducibility of the classification of ocular ferning patterns in Sjogren's syndrome patients]. Arq Bras Oftalmol 71: 228-233. [Crossref]

5. Abe T, Nakajima A, Matsunaga M, Sakuragi S, Komatsu M (1999) Decreased tear lactoferrin concentration in patients with chronic hepatitis C. Br J Ophthalmol 83: 684687. [Crossref]

6. Aragona P, Magazzù G, Macchia G, Bartolone S, Di Pasquale G, et al. (1999) Presence of antibodies against Helicobacter pylori and its heat-shock protein 60 in the serum of patients with Sjögren's syndrome. J Rheumatol 26: 1306-1311. [Crossref]

7. Felberg S, Dantas PE (2006) [Sjögren's syndrome: diagnosis and treatment]. Arq Bras Oftalmol 69: 959-963. [Crossref]

8. Vitali C, Bombardieri S, Jonsson R, Moutsopoulos HM, Alexander EL, et al. (2002) Classification criteria for Sjogren Syndrome: a reviset version of the European criteri proposed by the American European Consensus Group. Ann Rheum Dis 61: 554-558.

9. Limares FD1, Soler Rde C, Bussoloti Filho I (2005) [Lymphoma's manifestation in Sjögren's syndrome: is there a relation?]. Braz J Otorhinolaryngol 71: 342-345. [Crossref]

10. Mandel L, Surattanont F (2002) Bilateral parotid swelling: a review. Oral Surg Oral Med Oral Pathol Oral Radiol Endod 93: 221-237. [Crossref]

11. Abraham CM, al-Hashimi I, Haghighat N (1998) Evaluation of the levels of oral Candida in patients with Sjögren's syndrome. Oral Surg Oral Med Oral Pathol Oral Radiol Endod 86: 65-68. [Crossref]

12. Fox PC, Brennan M, Pillemer S, Radfar L, Yamano S, et al. (1998) Sjögren's syndrome: a model for dental care in the 21st century. $J$ Am Dent Assoc 129: 719-728. [Crossref]

13. Freitas TMC, Medeiros AMC, Oliveira PT, Lima KC (2004) Síndrome de Sjögren: revisão de literatura e acompanhamento de um caso clínico. Rev Bras Otorrinolaringol 70: $283-288$.

14. Hamburger J (2001) Sjögren's syndrome as seen by an oral physician. Scand $J$ Rheumatol Suppl 115: 34-38. [Crossref]

15. Mathews SA, Kurien BT, Scofield RH (2008) Oral manifestations of Sjögren's syndrome. J Dent Res 87: 308-318. [Crossref]

16. Neville BW (1998) Patologia das glândulas salivares. In: Veville BW, ET AL. Patologia Oral e Maxilo facial. $2^{\text {a }}$ Ed. Rio de Janeiro: Guanabara Koogan 314-352.

17. Sasaki RT, Ricci TC, Lima-Arsati YBO, Basting RT (2006) Alterações bucais em pacientes com Síndrome de Sjögren. Arq Odontol. 42: 161-256.

18. Bates JF, Adams D (1968) The influence of mental stress on the flow of saliva in man Arch Oral Biol 13: 593-596. [Crossref]

19. Feldman H (1974) Salivary buffer capacity, pH and stress. J Am Soc Psychosom Dent Med 21: 25-30. [Crossref]

20. Le Bell Y, Söderling E, Kirveskari P, Alanen P (1985) Flow rate, $\mathrm{pH}$ and buffer capacity of whole saliva before and after treatment of TMJ dysfunction. Proc Finn Dent Soc 81: 226-229. [Crossref]

21. Mandel ID, Wotman S (1976) The salivary secretions in health and disease. Oral Sc Rev : 25-47. [Crossref] 
22. Astor FC, Hanft KL, Ciocon JO (1999) Xerostomia: a prevalent condition in the elderly. Ear Nose Throat J 78: 476-479. [Crossref]

23. Jorkjend L, Johansson A, Johansson AK, Bergenholtz A (2003) Periodontitis, caries and salivary factors in Sjögren's Syndrome patients compared to sex and age-matched controls. J Oral Rehabil 30: 369-378. [Crossref]

24. Luz MAAC (1996) Cárie em pacientes com hipossalivação: aspectos clínicos, terapêuticos e preventivos. Rev Bras Odont 53: 27-31.
25. Pers JO, D'Arbonneau F, Devauchelle-Pensec V, Saraux A, Pennec YL, et al. (2005) Is Periodontal Disease Mediated by salivary BAFF in Sjögren's Syndrome?. Arthritis Rheum 52: 2411-2414. [Crossref]

26. Simmons DD, Al-Hashimi I, Haghighat N (2000) Effect of xerostomic medications on stimulated salivary flow rate in patients with Sjögren's syndrome. Quintessence Int 31 : 196-200. [Crossref]

Copyright: (C2017 Giovani ÉM. This is an open-access article distributed under the terms of the Creative Commons Attribution License, which permits unrestricted use, distribution, and reproduction in any medium, provided the original author and source are credited. 